\title{
バックエンド方式によりプロセッサを結合した $\mathrm{AI}$ ワークステーション「WINE」の構成法
}

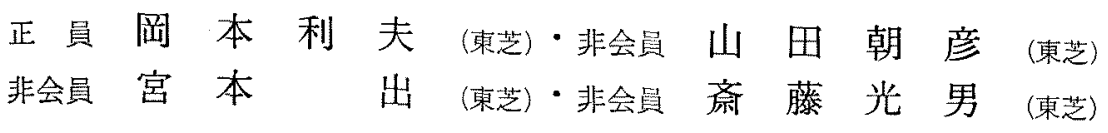

\section{1. まえがき}

近年人工知能の研究が急速に实用化に问りて進み， 棣々な応用システムの開発が進められている。それに ともない，応用システムを効率良く開発し，かつ実用 的怡速度で実行する AI 用計算機, 特にマンマシンイ ンタフェースのよい AI ワークステーションの開発 が強く望まれている。

徒来の AI ワークステーションは, Symbolics (1), PSI ${ }^{(2)}$ など代表される AI 言語専用ワークステーシ ョンか，または沉用のエンジニアリングワークスデー ション (EWS) に単に AI 言語処理系を载甘たもの であった。そのため，前者においては他言語て畫かれ たプログラムを実行するととができず，後者において は，AI 言語で書加扎たプログラムの実行速度が十分 でかった。

我々は，AI開発環境亡AI 言語ゆ実行形態の特徽 を考慮して，高速推論でしか子従来亡変わらない使い やすさを目標においた。その結果，AI プロセッサ (以下AIP と称する) を開発し，沉用の EWSをべー スに，バックェンド方式でプロセッサを結合する方 式の AI ワークステーション WINE (Workstation with Intelligent and Native Environment) 䦥発 した。雨者の機能を兼社備えた実用的な子のにするす ので, 広い応用䈖囲が期待されるあのである。

更に，AI 言語処理系の構成は，良来のバックエン ト方式での実現法（処理恶をすべてバックエンド側に

An AI Workstation "WINE" using Two Processors via Backend connection. By Toshio Okamoto, Member, Izuru Miyamoto, Non-member, Asahiko Yamada, Nonwember \& Mitsuo Saito, Non-member (TOSHIBA CORPORATION).

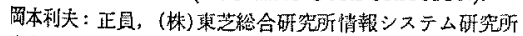

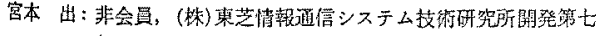
鄲

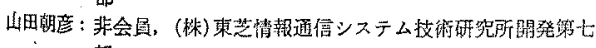
部

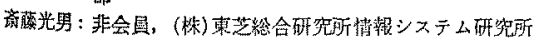

置く構成) (3)(4) とは珙なり，ホスト側にインタプリタ 部, AIP 睢にコンパイルされたオブジェクトをのせ る方式のため, 両プロセッサ間の通信回数が減少しオ 一バーヘッドを減らす構成にした。

その性能を澌定したとしろ，通常のアプリケーショ ンプログラムに打いては，上記の目標を満足したシス テムにすることができた。

本論文では，まずそのAI ワークステーションシス テムの目整とその構成法を述べ, 次にハードウェア， ソフトウェア上での雪現法を述べる。次に，AI 言語 の環境の構成法についてProlog 言語を例に之って述 ベる。最後に，通信のオーバーヘッドについて測定し て釷洒する。

\section{AI ワークステーションの開発目標と構成}

AI 用言語の特徵は，柔軟性が高いため，知識好理 のような複䧴であらかじめアルゴリズムの確定してい ない問題を解くために，試行錯愦をするのに非常に適 しているが，速度が䐅いのが難点と言われてきた。

そこで従来は，AI 言語で開発しアルゴリズムが確 定したのち，通常の䓹語に琴き替えるといった方法が 取られてきた。しかし，この方法はその乎間が大変に なってきて扰りまた多くのケースでは，書き替える ことが不可能になってきている。

例えば，実際の応用問題に扔いては，1,000ルール 程度が必要亡䣲われているが，てれを Prolog て 30 KLIPS (kilo Iogical inferences per second) 程度 $\omega$ 計算幾で解くし1時間以上か力ると言われており，奏 用にならない。このような問題空実用的な速度（数分 以内）で奏行てきるAI マシンが望まれていたて5。

そこでAI マシンが㤨えていなければならない機能 のうち

(1) 速度加早いこと（300 KLIPS 以上）。

(2) 目的に応じて，最適な言語でプログラムを開発 
し、しれらを組み合わせて夹行できること。

(3) 開発環境加良いこと。

の3点に重点在罳いて検討を進めた。

(1)の速度に対する検討を進めた結果，AI 用の言語 能率良く奏苗できるプロセッサが必須であることが わかった。

その結果, 考えら机る AI マシンの奏現帅態とし て，次の三つが考えられる。

(1) AI 強化 CPU に上るシングルブロセッサタ $イ フ^{\circ}(6)$

(2) AI 軎用コプロせッサタイプ(3)

(3) AI 専用バックエンドプロセッサタイプ(4) そのはか，並列プロセッサという実現法(7)6あるが， 実用域に達していない。この中で（3）のバックエン ドプロセッサタイプは，AI 用言語で書かれたプログ ラムと，ホスト上のプログラムとの結合を行う際に， プロセッサ間の通信が必要なため，多少能率が悪い。 しかし，要求(2)に関しては本体側に既にその機能が存 在するので，AI に関連した部分のみを開発す机ば良 い。むた，本体に比较的独立であるため比較的簢筆に 高性能を実現できるととと，他のマシンに移行しやす い点で有利である。また，要求(3)関しては，EWS 上の豊富な環境がそのまま利用できる。本 AI ワーク ステーションは，（）のバックェンドプロセッサタイ プで開発することにした。

次に，バタエンドプロセッサタイプとした場合， 両プロセッサ間の通信方式か間題となる。ここで，推 諭演算の特性について，数值演算のそれと比较してみ ると表1のようになる。

つまり，数值演算では数バイト程度のサイズの数值 データを繰返し何回む好理するのに対して, 推論では 数メガバイト程度の大きなデータベースを参照しなが ら推論を繰返す。そこで，AI マシンの性能は两プロ セッサ間のデータエリアの結合性能に大きく係わって くることになる。

以上の特性から図1のような構成を考えた。つま り，推諭処㻎はすべて AIP 上で行って高速推諭を実 現するのはもちろん， AIP はローカルなしかむ大容

表 1 数值演算と推論処理の特徽比較

Table 1. Comparison between numerical and infarential execution.

\begin{tabular}{|c|c|c|c|c|}
\hline & データサイス & 本ストとの通德 & 雪謤手段 & 秸合度 \\
\hline 数捑漼筑- & 小さい & 多 & Рプロセッサ & 夕夕卜 \\
\hline 推論処理 & 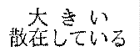 & 少ない & $\mid \begin{array}{l}\text { ハックエンド } \\
\text { プロ女ッササ }\end{array}$ & $u-x$ \\
\hline
\end{tabular}

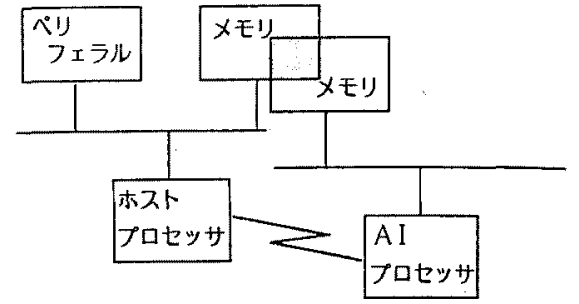

図 1 ホストプロセッサとAI プロセッサと の結合方法

Fig. 1. Connection model of multi processors (host processor and AI processor) system.

量のメモリを持ち，との中で推諭処理を行う。そのメ モり索ホストプロセッサのメモリの一部としてす报え るようにシェアする。こうすることにより，推論中の オーバーヘッドはなく，ホストが AIP のデータを参 想する際に発生するインタフェースのロスを最少限に 押さえることができる。

次に，入出力に関して鋥討する。既存のプログラム との整合性と，ホストマシンである EWS の利点で ある豊富な入出力装䇫をそのまま利用したいため， AIPでは，直接入出力制御は行わず，ホスト湖に任せ る維成にした。その際，通信の笚位は，入出力単位で はなく述語単位で行うことにより通信回数は少なくて きる。

最後に，同期制御に関するインタフェースの方式を 唡討する。上で述へたように，両者の通信が比較的少 なくできることから，部込み信号と，割込みハンドラ に上る通常の入出力装䈯と同様なやり方で十分である ことがわかった。

以上，本システムの構成を述べた。これを一言でま とめると，ホストプロセッサ側から見ると，AIPは， 巨大なメモリ索持った入出力装置のように見える。

\section{AI プロセッサのアーキテクチャ}

AI ワークスデーションのハードウェア棈成を图 2 に示す。ここで破鼣で国まれた部分が今回新たに開 発した AI 専用プロセッサ部分であり，それ以外は EWS (AS 3000 シリーズ) である。すなわち本構成 に拉いては，AI 言語で書かれたプログラムは曋用プ ロセッサで高速に実行され，通常の処理や，入出力な よ゙は EWS 本体が受け持つようにしている。

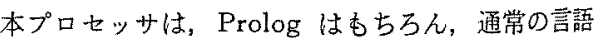
で毒かれたプログラムを高速に実行するアーキテクチ ヤを目標として検討を進め，LISP に関しても，高速 化が可能なように配慮して開発を進めた。 


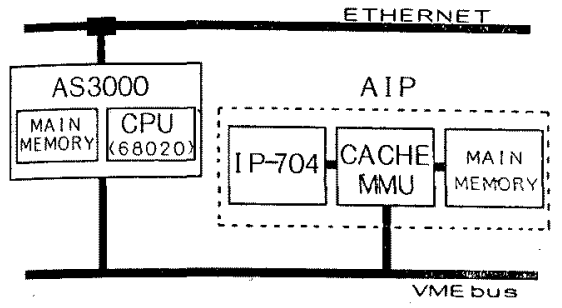

図 2 AI ワータステーションの ハードウェア構成

Fig. 2. Hardware architecture of $A I$ workstation.

その結果, RISC (Reduced Instruction Set Computer）風の通常命令，Prolog 処理用のマイクロコード によるD. Warren の提唱する仮想マシン命合 WAM (Warren Abstract Machine) ${ }^{(8)}$ の直接実行; および LISP の基本関数の直接実行, リアルタイムガーベジ コレクションのマイクロコードによるサポート，裉数 バスによる同時転送，命命よデータを分けたキャッシ ニメモリ，レジスタの退避・復元を高速に行うッイン レジスタを採用した高速なアーキテクチャとなってい る。その詳細については，文献(9)，(10)に述へられ ている。

ホストプロセッサとして，EWS の AS 3000 シリー

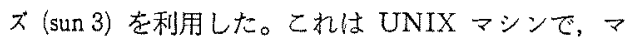
ルチウインドゥ (SunView)，分散ファイルシステム (NFS) などを搭載したワークステーションであり， 特にソフトゥェア開発環境に勝れたむのである。ま た，八ード的にも，VME バス（IEEE 1014）を採用 していて，ユーザが VME バス用のインタフェース ボードを付加できるように考虑されている。VMEバ スは，マルチバスとならんで広く普及しているバスの 一つである。

ホストプロセッサと AIP とは乙の VMEバスで 結合している。また，AIPをこの規格で製作すること で，他のホストマシン八の移值も容易であるう。デー タ3 32 ビット，アドレス 32 ビットの VME 空間上で AIPのメインメモリが $24 \mathrm{M}$ バイトの空間占占める。 AIP の制御レジスタも同漛にVME 架間につながっ ている。

\section{4. ソフトウェア構成}

とのようなシスデムの開発にあたっては，EWS の 開登摆境をつルに利用することを考え，段階的に開発 していく方針を取ったが, Prolog LISP ではその 方法は異なっている。

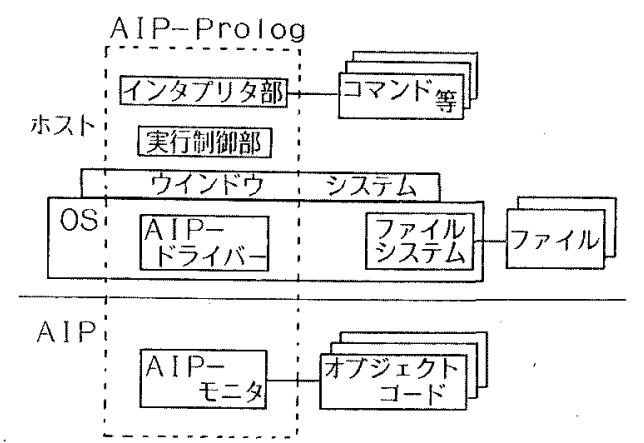

図 3 AI ワークステーションの ソフトゥェア構成

Fig. 3. Software architecture of AI workstation.

Prologは，言語としての歷史が浅く，いまだそれ ほよ゙たくさんのアプリケーションプログラムが蓄積し ていない。そのため，これから開発するための開発壊 境の充実の力が望まれている。よって，開発環境堂一 定に保ちつつ次第に実行速度圭上げていく方針で望ん tio

そ机に刘して，LISPは甈にソフトウェアの畒積が あるため，それらのプログラムが高速に実行できる万 がより強く望ま机ていた。そこで，最初からプログラ 么全体安 AIP 上で高速実行させることに重点老初い て開発を進めだは1)。

ここでは，以後，Prolog 言語に限定して話を谁め る。

AI ワークステーションの Prolog 閔係のソフトウ ェ了構成在四 3 亿示寸。この中で破線で囲んだ部分 が AIP を接綂するために開登した部分である。をれ 以外の部分は EWS 既存の季のを利用している。閒発 しなければならないプログラムには，EWS 上のむの 亡AIP 上のものがあるが，いずれも開発は EWS 上 で行うことができた。

このような棈成にすることにより，EWSと AIP 聞の通信は，AIP ドライバー上 AIP モニタの間で，

VME バスを介して行わ机る。ホストから AIP への リクエストは, OS (operating system) 内の AIP ド ライバーを象して，AIP モ二タ人伝光るAIP モ二 タは，その指示にしたがって AIP 上のオブジェクト を笑行させ，その結果をふたたび屰の経路でホストへ 返声。

この方法で，EWS と AIP の通信量定減らせば， 比䩙的容易に高性能を実現できる。このち式に䁷づ き, Prologコンパイラ学開した。 
ここではまず，モニタ，ドライバーなどの OSに倸 わるローレベルなインタフェースの構成法について述 べる。更に次章で，この上に構筑した Prolog コンパ イラに関して述べる。

〈4.1〉 データェリアのシェア EWS 上の各プ ロセスがアクセスするメモリはページと乎ばれる単位 に分制され OS で管理されている。そして，MMU (memory management unit) の仮想アドレスー物理 アドレス変換機能により，プロセスのアドレス空間 は、ページ単位汇実際のメモリに割当てられる。した がって，データェリアのシェアに関しては，この機能 を利用して寒現した。

つまり, AS 3000 の MMU 内の敦当エントリーに は，物理アドレスのタイプを表すフィールドがある。 ここを通常のメインメモリから VME 空間上の AIP のメモリに变更する。との処理は, AS 3000 の OSに 用意されている mmap と呼ばれるルーチンを用いて 実現できる。一度マッピングを変更すると以後, 它の ページへのアクセスはシステムコールなしに，VME 空間の绉当メモリへアクセスする。との方式により， ホストは入出力汇必要なデータを直接アクセスする ことができ，不用なデータのコピーを防ぐことができ る。

〈4.2〉同期制御 次经同期制御に関して述べる。

VME バス上の割込灭信号利用した。OS 内に割 込みハンドラとよぶソフトウェアを用意する。これは 通常の入出力 $(\mathrm{I} / \mathrm{O})$ 機器へのハンドリングの仕方と 同様である。

具体的飞络, AIP の同期制御はUNIX の入出力用 のシステムコールで行う。UNIX ではユーザーが作 成した $\mathrm{I} / \mathrm{O}$ デバイス用のドライバーソフト OS の カーネル内のテーブルに登録することで実現できる。 そこで, AIP 用のデバイスドライバーを作成し，ここ に登録する。したがって，ユーザープログラムの中加 ら AIP 用の I/O システムコール (AIP コール) を発 生することにより AIP 同期実行させる。こてで, AIP ドライバーのアルゴリズムについて説明する (図 4)。まず，ドライバーは，AIP のコントロール レジスタ中に AIP のプログラムカウンタをセットし STOP フラグを OFF にすることで，AIP が指示さ れたアドレスから動き出す。そして，その間ドライバ 一はスリープしてその終了を待つ。AIP は処理が終 了すると割込み信号を発生する。これを，ホストのカ 一ネル中の割込みハンドラーが受け，スリープしてい るドライバーを起こす。よって，てれで，AIP のド ライバーか再じ動きだす。するとドライバーは AIP

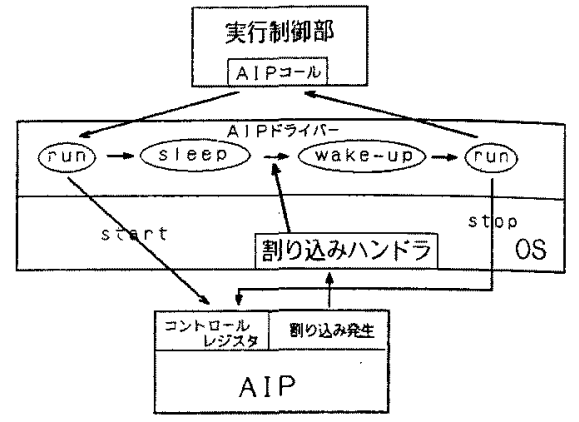

図 4 同期制御

Fig. 4. Overview of synchronous control section.

を再び停止させ，呼び出し元へすよ゙る。

\section{Prolog 言語環境}

ここでは，前章で述べた結合法を用いて，どのよう に Prolog 言語環境を構築したがついて述へる。

〈5.1〉Prolog 言語の特性 Prolog 言語は, そ の言語を用いる状況を考えてみると，実行環境のみな らず，開発環境も重要である。つまり，新しい丁イデ イてを実証するプロトタイプ作成の場となること加 必要である。そのため，試行錯䛊を綝返す。したがっ て，基本之なる実行方式はインタプリタ方式が望まし い。しかし，インタプリタ方式ではその方式上，案行 速度が上がらない。よって仕様の固まったところは逐 次コンパイルして実行速度を上げ，開発效率を上げ る。

てのような AI 言語用の開発環境を考えて, 本処理 系では，インタプリタ・コンパイラ方式，つまり，1 ンタプリタ環境中からコンパイルし，それを実行する 方式を採用した。

〈5.2〉インタフェース 次に, インタプリタ・ コンパイラ力式によるProlog 環境において，二つの プロセッサへの処理の分割法を检討する。

AIP と EWS との結合がルーズであるので、いか に通信回数を減らすかがポイントになる。開発目標で 述べたように，その目的は，

インタプリタ㑡 使いやすい環境

オブジェクト側 高速実行環境

と言える。

インタプリタ側は，主にユーザとのマンマシンイン タフェースを报う。また，UNIX のファイルとのや りとりも多い。したがって，インタプリタ部は，入出 力関係の処理が多い。そとで，インタプリタ部をホ スト側に持っていく。すると，入出力に関してホスト 


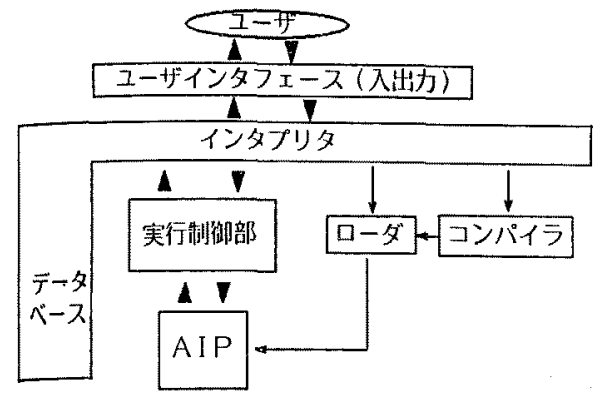

図 5 Prolog 言語環境

Fig. 5. Environment of Prolog language.

とAIP 間の通信回数が少なくなり、オーバーヘッド がさくなるまた，AIP 側に入出力装置用のドラ イバーが不用になり AIP 側のモニタがコンパクトに はる。

一方，オブジェクト㑡仙高速実行のみ老目的上す る。その間は，ホストからの干渉を受けないようにす る。

以上により、インタプリタ部は AIP 㑡よりホスト 例们あるのがよいと結論した。

“次凩者間のインタフェースについて考察する。使 いやすい開発環境亡なるにはインクリメンタルロー ダ、つまり部分コンパイル・部分ローディングが必要 である。この方式では害行時にならないと，呼び出さ れる述語がコンパイル済みかどうか決定できない。 ソパイルさ机ていない述語（以下，ソース述語之記 す)の実行は，インタプリタ側で代行するととにな る。したがって，実行時にインタラクティブにインタ ナ゙リ夕側での実行とオブジェクト側での実行を切り替 元る実行制御部が必要になる。これらを図示する上， 图5のようになる。また，インタプリタ側とオブジェ クト側で报うデータの表現形式が異なるので実行制御 部内にデータ変换部が必要になる。

〈5.3〉インタプリタ＼cjkstart次にベース之なるインタ フリ夕の選択について検討する。0から作っていけ ば，開発期間がかかる。また，EWS 上には既に利用 されているProlog 処理系が存在する。したがって, 今回は既存のインタプリタ上にコンパイラ環境を付け 加えた。つまり，コンパイラ部，ローダ部，実行制御 部学新しく作成してインプリメントした。

ベースとなるインタプリタとして C-Prolog を利 用した。とれは中核部分はすへて $\mathrm{C}$ 言語で記述されて いる。実行制御部のような，細汃所を記述する必要 のあるあのでは，C言語で書くのが滴している。よっ て，実行制徂部を理め込むには，C言語で書かれてい
るCーProlog 処理系が避している。ただし，内部の データ表現が，WAM のそれと異なるので，実行制御 部の中にデータ変換部を作成し, データの差異をここ て吸収している。との方式では，インタフェースの負 担が大きいが，特殊なケースを除き，全体的な性能に は影敏が少ない上考え採用した。

〈5.4〉実行制御部次に実行制御部について述 べる。先に述べたようにててでは，インタプリタ上で 実行中にコンパイル済みの述語（以下，オブジェクト 述語と記す）を呼び出す場合，および，逆にオブジェ クト上で寒行中にソース述語を呼び出すための制御を 行う。

両者の間で制御が切替わるポイントは，次の六つあ る。

(1) ソース述語（インタプリタ側）からオブジェク クト述語を呼び出す場合。

(2) (1)に対し，その述語の実行が成沶して呼び出し 元へ屃る場合。

(3) (1)に対し，その述語の実行が失敗して呼び出し 元へ屃る場合。

(4) オブシェクト述語からンース述語を呼び出す場 合。

(5) (4)に対し，その述語の実行が成功して呼び出し 元八㞍石場合。

(6) (4)対し，その述語の実行が失敗して呼び出し 元へ㞍る場合。

以上，六つの場合に制趐の切替えが必要である。こ のときに，実行制御部がまず呼ばれる。実行制御部で は，上のどのケースで呼ばれたが判断する。(1)(2)(4) (5)に対しては，更にデータ変換部を読出しデータを相 手に合わせて変換する。(1)(4)では，指定された述語を 実行させる。(2)(5)では、(1)(4)を呼び出した述語の続き を棒行させるようにする。(3)6では，(1)(4)を呼び出し た述語が失敗した状態にさせ，代替の述語を実行させ る。

〈5.5〉実行制御部のオーバーヘッドの検討 こ こで, 問題になるのは，上で述べたデータ変換部であ る。インタプリタ側とオブジェクト側とで、データ表 現が異なる。よって，实行が切り替わるごとにデータ 変㨦をしなくてはいけない。ソース述語とオブジェク 卜述語之が入り交り，変換するデータ量が多くなる と，オーバーへッドか增加し，実行速度はそれはど向 上しないととが考えられる。

この上うなソース述語とオブジェクト述語が交差し て実行されるケースは以下の通りである。

(1) アプリケーションの開発途上。 
(2) 組み込み述語を多用している屯の。

(1)のケースでは，開発段階の初期の状態に相当す る。確かに雨者のタイプの述語が混在する。しかし， アプリケーションプログラムが完成するにしたがっ て，ソース述語の比率が低下するので，実行速度は向 上していく。そのため，特に間題はないと考える。

(2)のケースでは，プログラムが完成した後ですオブ ジュト側で詨応しない組子込子述語が存在すると， インタプリタ側で奉行することになるので，てのよう なプログラムでは実行速磨はそれほど向上しない。

ここで，組み闪み述語を二つのタイプに分りる。

(1) ライブラリ一化可能なオブジェクト述溒

（2）ライブラリー化困難なオブジェクト述語

（1）は，算術演算述語がその好例である。これは， 頻繁に用いられる。とこに虽する述語は、コンパイル 化したライブラリー上することが容易である。したが って、インタプリタへ制御を切り替える必要がなく, オーバーヘッドの問題はまったく起きない。

(2)は, assert, retract 述語などのデータベース操 作関係の述語に相当し, 容易にライブラリー化が困難 な述語である。このような述語は，プログラムの実行 初期段階に現れるととが多く，比較的プログラムの外 側のループて使わ机るケースが多い。したがって、ソ 一ス述語しして，そのまま残しておいてむ，それはよ゙ 鰂担になることはないと考えた。

評洒の章でこのオーバーヘッドに関する測定を行 い，この点について間題ないことを確認した。

\section{6. 評価}

ここではまず,マルチプロセッサ間での通信量を個 個の要素に分けて测定した。

今までの考察に基ついて,

(1) シェアドメモリによるオーパーヘッド

(2) 実行制御に関するオーバーヘッド

(3) データ変換に関するオーバーヘッド

に予けて测定した。

次江具体的な例題プログラムで，その総合的な影響

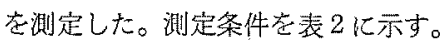

〈6.1〉シェアドメモリのオーバーヘッド＼cjkstart測定 はインタプリタ上で行い、データエリアがメインメモ リにある場合と，AIP のシェアドィモリにある場合 とで比校した。

テストプログラムは, Prolog コンテスト ${ }^{(12)}$ 中中 8クィーンの全解を求めるものを用いた。

测定は，組み込み関数の cputime 有いて测定し た。この関数は, UNIX のシステムコール times を
表 2 システム構成

Table 2. System overview.

\begin{tabular}{|c|c|}
\hline ホス卜部 & \\
\hline システム名 & 柬芝 AS 3160 \\
\hline プロセッサ & $\mathrm{MC} 68020 \quad 16.67 \mathrm{MHz}$ \\
\hline メインメモリ & $8 \mathrm{M}$ Byte \\
\hline ディスク & $\begin{array}{l}\text { ネットワークファイルシステム (NFS) } \\
\text { OS/AS V V } 3.0\end{array}$ \\
\hline AIP 部 & \\
\hline $\begin{array}{l}\text { ナロせッサ } \\
\text { メインメモリ }\end{array}$ & $\begin{array}{l}\text { IP } 704 \text { V } 1.010 \mathrm{MHz} \\
24 \mathrm{M} \text { Byte }\end{array}$ \\
\hline$\because 71$ & \\
\hline $\begin{array}{l}\text { インタプリタ } \\
\text { コンパイラ }\end{array}$ & $\begin{array}{ll}\text { C-Prolog V } 1.5 \\
\text { AIP-Prolog V } 1.0\end{array}$ \\
\hline
\end{tabular}

表 3 シェアドメモリによるオーバーヘッド

Table 3. Overhead for shared memory.

\begin{tabular}{c|c|c}
\hline & メインメモリ & シェアドモり \\
\hline 時 間 & $46.21 \mathrm{~s}$ & $52.63 \mathrm{~s}$ \\
\hline 比 & 1.0 & 1.14 \\
\hline
\end{tabular}

表 4 実行制御部によるオーバーヘッド

Table 4. Overhead for execution control section.

\begin{tabular}{c|c|c}
\hline & 200 回コールの测定時間 & 1 回あたり \\
\hline 時 間 & $0.68 \mathrm{~s}$ & $3.41 \mathrm{~ms}$ \\
\hline
\end{tabular}

実行し，その結果中のユーザータイムを值として迡す あのである。测定精度は $1 / 60$ 秒である。

测定は各々 10 回行い, その平均值を算出した。結 果を表 3 に示す。

これでわかるように、シェアドメモリを用いると 14\%インタプリタの速度が低下している。前に述へ たように，プログラムの閒発段階初期にはこのオーバ 一ヘッドがきいてくるが，開発が終かれば一部の組み 込み述語を除いてすべてオブジェクト化するので影锌 はかなり低下し，問題はなくなる。

〈6.2〉実行制御部のオーバーヘッド実行制橎 部のオーバーへッドのうち、デー夕変換を除いたもの 在测定する。

$$
\text { とれは、プログラムとして。 }
$$

test.

という述語を，コンパイルしてオブジェクト化する。 そして，200回とのオブジェクト述語を呼び出すテス トプログラムを作成した。しれを10回絽り返し，そ の平均時間を算出した。

测定は, UNIX のライブラリー関数 ftime を用い た。測定精度は $1 / 100$ 秒程度である。結果を表 4 に示 す。 
とのテストプログラムでは，次の部分の奏時間を測 定したことになる。

(1) 实行制到部本体

(2) AIP ドライバー

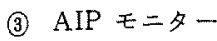

(4) オブジェクト述語 “test”

とのうち，(4)の部分は，そのオブジェクトコードが

数命令しかないので実行時間はほよんどはい。よっ て、澌定時間は実行制御のオーバーヘッドのみと見な せる。

湘定結果では，AIP の命令実行速度（1 命令最低

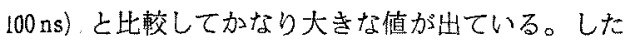
がって，なるべく通信回数を減らすことが必要であ る。よって，本方式のように入出力をまとめて行う方 式は有効であることが確㷵できた。

この测定は，寒時間で測定しているため，その間に ホスト上のインタプリタのプロセスがスケジューリン グによりスリープしてむ，その閻の時間が湘定時間に 入ってしまう。AIP をマルチプロセス化す机でての 㭙間は減るものと思わ机る。

$\langle 6.3\rangle$ データ変換のオーバーヘッド 前節の湘 定で除いたデータ变換部のオーバーへッドを測定す る。この時間はデータの大ささに比例する。ここでは 要菜 100 個のリスト 10 個を,

(1) インタプリタからオブジェクトの形式に翌換

(2) その逆変換

の実行時間を测定した。

澌定には UNIX のシステムコール times を用い， そのユーザタイムを測定した。10回测定し，その平均 時間を算出した。測定精度は $1 / 60$ 秒である。

剆定結果を表 5 亿示す。

実祭には，このような苛酷なデータをやりよりする ことはほとんどないと思われる。

データ変授姏理は，数值やアトムのようなデータタ イプでは両方向で各1回ずつ変換すればよい。ところ が;リストやストラクチャタイプのデータではその要 素数分，変撸する必要がある。一つの述語あたり 5 回 データ变換すると仮定すると，両方向で 10 回かかる。

表 5 データ変換部によるオーバーヘッド

Table 5. Overhead for data conversion section.

\begin{tabular}{|c|c|c|c|c|c|}
\hline & 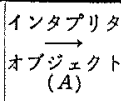 & 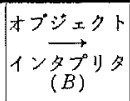 & $\begin{array}{l}\text { 合 尌 } \\
(A+B)\end{array}$ & $\mid \begin{array}{c}1 \text { 引 数 } \\
\text { क } 6 \\
\left(\frac{A+B}{10}\right)\end{array}$ & 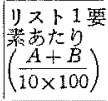 \\
\hline 時 間 & $143.3 \mathrm{~ms}$ & $161.7 \mathrm{~ms}$ & $305.0 \mathrm{~ms}$ & $30.5 \mathrm{~ms}$ & $0.305 \mathrm{~ms}$ \\
\hline
\end{tabular}

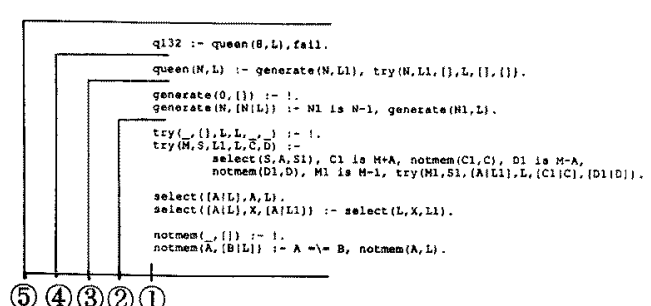

(5) (4)(3)(2)(1)

図 6 テストプログラム:「8クィーン」

Fig. 6. Test program: "8 Queens".

表 68 クィーンの灵行時間

Table 6. Execution time of 8 Queens.

\begin{tabular}{|c|c|c|c|c|c|}
\hline & (1) & (2) & (3) & (4) & (5) \\
\hline 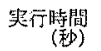 & 52.63 & 2.78 & 2.81 & 2.60 & 0.55 \\
\hline
\end{tabular}

すると，变換時間は約 $3 \mathrm{~ms}$ となり，制徂变換の時間 と同程度の時間がかかる。よって、ソース述語とオブ ジェクト述語が引き渡すデータ量, 特にリスト。スト ラクチャを堿らすととが有効である。

Prolog のプログラム中では，リスト処理がかなり あるのが普通である。しかし，それらの処理は AIP 内でのみ行わ机る。入出力の述語に代表されるッース 述語では，扱うデータ星は限られているので大きな問 題にはならないと思わ㞦る。

〈6.4〉総合俩価 次に，サンプルプログラムを あとに，開発過程のモデル上での総合的なオーバーへ ッドを测定した。

測定は，次のように行った。サンプルプログラムと して，8クィーンの問題を再び選んだ。そして，プロ グラムの開発作業をモデル化して，以下に示すソース 述語とオブジェクト述語の混在のパターンを作成し た。これは，图6に示すように一番下位のルーチンか らコンパイルしていく，一般的な使われ方を想定して いる。

〈開発作業のモデル〉

(1) すべての述語が未コンパイル。(開発初期)

(2) try 述語以下がコンパイル斎み。

(3) generate, try 述語以下がコンパイル斉み。

(4) queen 述語以下がコンパイル済み。

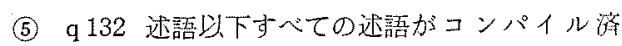
7. (開発完了)

実験方法は今までट同様なやり方で行った。表 6 に 結果を示す。また，文献(13)に他システムで行った奏 行時間が述べられている。

この結果より次のととが扐る。まず，オブジェク ト化彎が上゙るにしたがって（番号が大さくなるのに 
したがって)，実行時間が小さくなっている。てれは予 想された結果である。とてろが，(2)と(3)の間では，才 ブジェクト化率が上がっているに白かかからず，逆に 笑行時間が少し增えている。乙れは，まだソース述語 のままである queen 述語加らると, generate 述語 上，try 述語を並列に呼んでいる。ことで，(2)では， オブジェクト化されたのはtry 述語だけであるので， ここだけ笑行制御部を経て実行される。ところが，(3) では, try 述語と generate 述語の二つ,つまり 2 回 実行制制部を通らないといけない。このたるにオー バーヘッドが增えたものである。

次に，速度の向上の比率をみると，(1)から(2)，(4)か ら(5)の間が大きい。これは，queen 述語，および try 述語の中での滞在時間が長いためである。つまり, 一 度, これらの述語を実行し始めるとその中にとどまっ て、推論を繰り返す。その分, 実行制御部を通らなく なり，高速実行可能となった。

以上の考察をまめると，以下の上うになる。

（1）概して，オブジェクトの部分が増すにしたが って，実行時間は減少する。

（2）オブジェクト述語とソース述語が交錯してい る場合には，その効果が低下する。

（3）（2）の場合とは逆に，内部で推諭処理が㸿く 簓所で区切りながらコンパイルしていくとその効果は 非常に大きい。

以上より，本方式が，プログラム開発の場において あ，大きなオーバーへッドなしに高速実行できること がわかった。

\section{7. 終わりに}

以上 AI ワークステーションに関し, 主に, EWS のホストプロセッサと AIP のバックエンドプロセッ サ間のマルチプロセッサ方式の実現法とその評価次 いて述べ。

バックエンド方式の長所としては，ホストマシンに 依存しない高性能の推論驾可能であり, かつ, ホスト 上のインタプリタと結合して用いるてとにより，実用 的な環境屯伴ったシステムができることがあげられ る。

欠点としてはその間の通信量が多くなるとロスが多 くなるのでひんばんにホストとやりとりする形での インプリメントには向かないことである。

本方式では，AI 言語の特性を分析し，大容量のデ
ータエリアとの交信はシェアドメモリの方法で行い， OS からのオーバーヘッドを避けている。更に，実行 の切替え制御に関しては、オブジェクト述語とンース 述語間で行い，通信量の少ない筒所で行った。

評価としては、シェアドメモリに対するシステムの ロスタイムは，システムに大きな影響を与えないるの の，寒行制御のロスタイムはオブジェクトコードの実 行速度と比較して大きく, ソース述語とオブシェット 述語をひんぱんにやりとりするアプリケーションで は，性能が十分に発揮できない。しかし，そのような ケースは, アプリケーションプログラムの開発途上で は起き得るが, 開発途上のケースにおいてす十分高速 に実行できることと，また，すべての述語をコンパイ ル化した完成されたケースでは，一部のライブラリー 化が困雎な組み込み述語を使っていないがきり問題な いことがわかった。

このような組み込み述語は限られていて，加ま た，推諭の核の所には使わ机ないので，実行時間の才 ーバーヘッドに関し大きな問題にはならないことがわ かった。

(昭和 62 年 10 月 26 日受付)

\section{文献}

(1) D. A. Moon: "Architecture of the Symbolics 3600", Proc. of the 12th Annual Int'l. Sympositum on Computer Ar. chitecture, 191 (1985)

(2) S. Uchida, et al.: "Outline of the Personal Sequential Inference Machine: PSI" New Generation Computing, 1 -2 (1983)

(3) T.P. Dobry: "A Coprocessor for AI; LISP, Prolog and Data Bases", Compcon 87, 396 (1987)

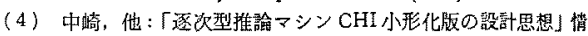
報姏理学全第 33 回全国大会 5B-6 (1987)

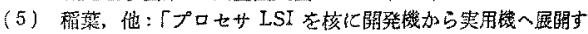
る AI 霜用マシン」日経エレクトロニクス, 1987.1. 12,91

(6) S. Abe, et al.: "High Performance Integrated Prolog Processor IPP" Proc. of the 14th Annual Int'l. Symposium on Computer Architecture, 100 (1987)

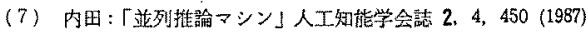

(8) D.H.D. Warren: "An Abstruct Prolog Instruction Set" Tech. report 309, Artifitial Intelligence Center, SRI International (1983)

（9）相川，他：「AIプロセサーのアー-.キテクチャ」人工知能学会 解 1 回全国大金, 241 (1987)

(10) 相川, 倪:「AI ワークステーション (WINE) の销発II IP 704 の厂ーキテクチャ」情赫処理学全第 35 回全国大会 $6 \mathrm{M}$ 5 (1987)

(11) 河久, 他:「AIワークステーション(WINE)の開発V LISP コンパイラ」情報処理学会第 35 回全国大念 $6 \mathrm{M}-9$ (1987)

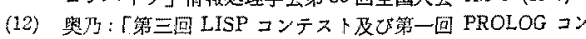

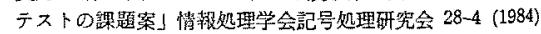

(13) H. Okuno: "The Report of The Third Lisp Contest and The First Prolog Contest" 㨨坏姏理学会記号知理研究会 33-4 (1985) 